\title{
English Coursebook Adoption Processes for Junior High Schools in Japan
}

\section{David A. Hammett \\ Hokkaido University of Education}

\section{Reference Data:}

Hammett, D. A. (2020). English coursebook adoption processes for junior high schools in Japan. In P. Clements, A. Krause, \& R. Gentry, Teacher efficacy, learner agency. Tokyo: JALT. https://doi.org/10.37546/JALTPCP2019-08

In Japan, each municipal or prefectural board of education (BOE) is responsible for selecting its own coursebook series to be used in English lessons for nation-wide, compulsory education own coursebook series to be used in English lessons for nation-wide, compulsory education
courses (elementary through junior high school) and in high school. This paper is a report on the investigation of the official governmental websites of five municipal or prefectural BOEs to find what kinds of methods they currently use for the selection process of English coursebooks for junior high school (JHS). The processes employed by the BOEs were examined. It appears that the criteria BOEs use for selection differ and may not be firmly grounded in research on SLA and materials evaluation. Another consequence of the strategies used by BOEs is that they may be less inclined to adopt different coursebook series than those used in previous years.

日本では、各市町村または県の教育委員会 (BOE) が、小学校から中学校の義務教育及び高校の英語の授業で使用する独 自の教科書を選択する責任がある。本論文では、政府の公式ウエブサイト上の5つの教育委員会を調査して、BOEが中学校英 語の教科書採択に現在どのような方法を採用しているかについて報告する。BOEで採用されている教科書採択方法を調べた ところ、各BOEによって基準は多少異なり、SLAと教材評価の研究にしっかりと基づいていない可能性がある。BOEによっては、 前年度で使用されたものとは異なる英語教科書を採用する事に消極的である可能性もある。

nglish coursebook usage is estimated to constitute roughly $70 \%$ of the classroom time that junior high school (JHS) students spend for English study purposes in Japan (Sanseido Publications, 2017). With so much of the associated teaching and learning being conducted in the classroom, coursebooks largely determine what teachers will teach, and in effect, has an impact on how learners will learn. Consequently, the decision to use one coursebook over another should probably not be taken lightly (McGrath, 2016). This may be why coursebook evaluation (a tool for coursebook decision making) has become a discipline that has received notable academic attention in recent years (Azarnoosh, Zeraatpishe, Faravani, \& Kargozari, 2018; McGrath, 2016; Tomlinson \& Masuhara, 2017).

Evaluation "involves the making of judgments" and in the case of coursebooks would be judgments regarding their quality or suitability (McGrath, 2016, p. 28) or as Littlejohn (2011) considers it, a coursebook's "worth for specified purposes or contexts" (p. 181). Evaluation is concerned with whether a coursebook's contents meet contextual requirements, and if so, making a judgement about its quality or suitability (McGrath, 2016). Those persons evaluating coursebooks need to be careful because when they look selectively at a coursebook, if they do not have a comprehensive checklist of what is important for their specific context, they can potentially "miss the unusual and reject the innovative" (McGrath, 2016, p. 29). Further, adhering to BOE checklists may encourage publishers and authors to reproduce the status quo at the cost of innovation. Creativity could potentially be overlooked in the process of evaluation and as a result be seen as not worth the effort of including. ${ }^{1}$

According to Tomlinson and Masuhara (2017), materials evaluation in general and coursebook evaluation in particular should involve attempts to predict or measure the macro and micro value of the presented materials to language learning. "Macro effects [can include] the understanding and production of language, the acquisition of language, the development of language skills and the development of communicative competence" (p. 52). "Micro effects [refer to] engagement, motivation, self-reflection, self-esteem, autonomy and attitudes toward the target language and the learning of it" (ibid.). 


\section{Contemporary English Education in Japan}

English education in Japan seems to have become an object of necessary reform for the Ministry of Education (MEXT) in recent years, leading up to the Tokyo Olympics (Hino, 2018). In 2014, MEXT wrote a report addressing English proficiency as "crucial for Japan's future" amid "rapid globalization" (MEXT, 2014, para. 1-3). English knowledge encompassed by the four skills (reading, writing, listening, and speaking) is still a focus, but the "abilities to reason, make decisions or express oneself" also appear to have come into the spotlight (para. 3). Further, top-down administrative proposals for how reform should take place have become solidified into the timeline of implementation. MEXT's nation-wide English education reform goals are directed towards different facets of the education system in order for a comprehensive, timely, cost-efficient, and ultimately successful reformation to take place (MEXT, 2017).

\section{MEXT Guidelines for English Education and Reform}

In April 2011, new guidelines for elementary schools were fully implemented in which English became a compulsory subject for all fifth and sixth grade students. In April 2018, the required number of hours for fifth and sixth grade elementary English lessons were increased from 45 to 90 hours each school year. These changes reflect a popular SLA belief that second languages are easier to acquire through early exposure. This also reflects MEXT's claim that early exposure fosters "a positive attitude toward communication" (MEXT, 2008: cited in Tahira, 2012, p. 4). Homeroom teachers are to be responsible for such classes (Fennelly \& Luxton, 2011). The reason for this could be because they are the teachers most familiar with the students and are therefore the ones who could best help students deal with language learning anxiety and encourage willingness to communicate (MEXT, 2008; Tahira, 2012).

Besides increasing the number of hours for English lessons, methods of teaching have also been identified as an area in need of revision. As such, updated guidelines and procedures for teaching English lessons have been mandated for elementary school English courses. These guidelines follow methods that use English for communicative purposes, such as the British Council's Can-Do English program (Sanseido Publications, 2017). The aim of directions taken in elementary school is to gradually move away from repetitive exercises and rote memory techniques toward more communicative activities, such as those that develop students' capacity to express their likes and dislikes, make inferences, give opinions, and complete information gap activities. It follows that the coursebooks used for teaching these revised guidelines should reflect this new outlook on what English proficiency should ultimately become. The aim of such changes means that the focus of learning is not limited to academic learning, but rather that language acquisition is a means of expressing oneself and relating to others.

The Value of Coursebooks

In a 1953 article "Is a Textbook Really Necessary?" West argued, "A textbook is necessary, the pupil keenly feels the need of one... even with a lesson every day, much of today's teaching has faded by tomorrow" (cited in McGrath, 2016, p. 14). Numerous arguments in favor of using coursebooks in language programs were summarized by McGrath (2016) based on findings from other researchers such as Grant (1987), O'Neill (1993), Richards (2001), and Ur (1996) as follows:

Teachers and learners need coursebooks because they

1. Are maps, which show where one is going and where one has been;

2. Provide language samples; and

3. Offer a variety of target language, activities, and topics.

Learners need coursebooks because they

4. Define what is to be learned and what will be tested; and

5. Reinforce what the teacher has done, make revision and preparation possible, and thus offer support for learning outside class.

Teachers need coursebooks because they

6. Provide structure for teaching;

7. Save time since requiring teachers to make materials anew for every lesson would be unreasonable;

8. Offer linguistic, cultural and methodological support; and

9. Make it easy to keep track of what the teacher has done, so that others can be consulted with (e.g., colleagues, principal, parents). (McGrath, 2016, pp. 14-15)

The importance of coursebooks should not be overlooked as teachers are expected to teach from them. According to anecdotal evidence from experienced JHS teachers in Sapporo, coursebooks contain not just target grammar, but also the vocabulary that 
students will need to know in order to successfully take the English battery for high school entrance examinations in Japan (Hirota, Kasuga, \& Matsumoto, 2020, personal interview). Similar circumstances in other teaching contexts likely lead Yuen to compare teacher dependence on coursebooks as a virtual marriage in which coursebooks are an "inevitable teaching partner" that one "cannot [...] ask for a divorce" (Yuen, 1997, p. 5). Coursebooks can serve as teachers' career companions in their lessons and, as such, direct a reasonable degree of what is taught and how it is taught. It follows that a coursebook, when created with a learner-centered methodology in mind, can serve as a support for the teacher who is using it. Conversely, coursebooks could become stumbling blocks to teachers when they are not created with the target curriculum and methodology as the focus of the learning process (Glasgow \& Paller, 2013).

\section{MEXT-Approved Coursebooks}

In Japan, the Ministry of Education requires that all coursebooks used in compulsory educational programs be subject to an approval process by appointed evaluators (Tomlinson \& Masuhara, 2017). Evaluators are required to look at each coursebook and decide if it matches current national curricula and guidelines. However, municipa and prefectural BOEs make the final decisions as to which coursebooks will be used in schools within their jurisdiction (Tomlinson \& Masuhara, 2017). Coursebooks of any discipline published for use in public schools in Japan must go through a selection process, which includes governmental examination before subsequent adoption. Publishers must first produce a coursebook series for a given subject, within the appropriate guidelines, as well as adapt materials to meet the changing demands of the market, such as course design, layout, and graphic design or strategic choices that differentiate their coursebook series from those of their competitors. After their coursebooks are finished, publishers need to reapply for government examination. After a coursebook series is accepted for examination by MEXT, a panel of appointed coursebook experts examine the coursebooks to determine its suitability for inclusion in school curricula (MEXT, 2014). Coursebooks must then undergo a second inspection by the Textbook Approval and Research Council.

Once approved, coursebooks are allowed to be used within schools across Japan, including public, private, and national schools. In turn, each BOE for public schools, principals, and committees of private and national schools must then decide which coursebook series to adopt for use. MEXT has stated that each prefectural BOE should establish coursebook selection committees of their own and appoint members for the purpose of examining coursebooks and then give recommendations via selection statements, called sentei riyuu-sho (選定理由書) (MEXT, 2019). After considering the advice given in the selection statements, BOEs choose a coursebook series for adoption and compile a report for each course of study (including math, English, Japanese, and science) (MEXT, 2019). Based on the reports submitted by BOEs, the Minister of Education then issues instructions to each publisher that designate how many copies of each are to be published. The Japanese government covers the costs of all coursebooks produced for compulsory-level programs, which are those from elementary school through JHS (MEXT, 2014).

JHS in Japan spans 3 years, and one coursebook is used for each grade level. To simplify this process, a BOE can select a coursebook series that is designed to be used sequentially across each grade. The English language coursebooks used in JHSs across Japan can vary from city to city, since each municipal BOE has the discretion to select from MEXTapproved series. There are, at this time, six MEXT-approved coursebook series for use in JHS English language programs. Generally, the selected coursebook series will be used for the next 4 school years, as coursebook publishers are encouraged by MEXT to make revisions to their coursebook series only every 4 years (MEXT, 2019).

\section{Research Questions}

This study was aimed at uncovering what methods are used and what factors are considered when BOEs decide which coursebooks to adopt for use for compulsory English study in Japanese JHSs. In particular, in this paper I seek to address the following research questions:

RQ1. What processes are employed in coursebook selection?

RQ2. What criteria are considered by BOEs when deciding which English coursebook series to adopt?

\section{Method}

The data for this study were primarily collected from the governmental websites of five municipal or prefectural BOEs. Each municipal and prefectural BOE has its own official website, where information regarding the English coursebook used can be found. The data included in this study covered (a) the coursebook series selected by each school or BOE and (b) documentation relevant to the justification for selection of a particular coursebook series.

If the above information was not available on the respective websites, the BOE was contacted directly via email with an enquiry requesting the data for public research. The 
evaluation information related to the coursebook selection process from each $\mathrm{BOE}$ was translated into English and then summarized.

\section{JHS Coursebook Adoption in Japan}

Figure 1 is a map of Japan. The areas noted on the map were chosen as representative BOEs for each of the five major islands of Japan, because the chosen BOEs (with the exception of Chiba) have some of the largest student populations for their respective island.

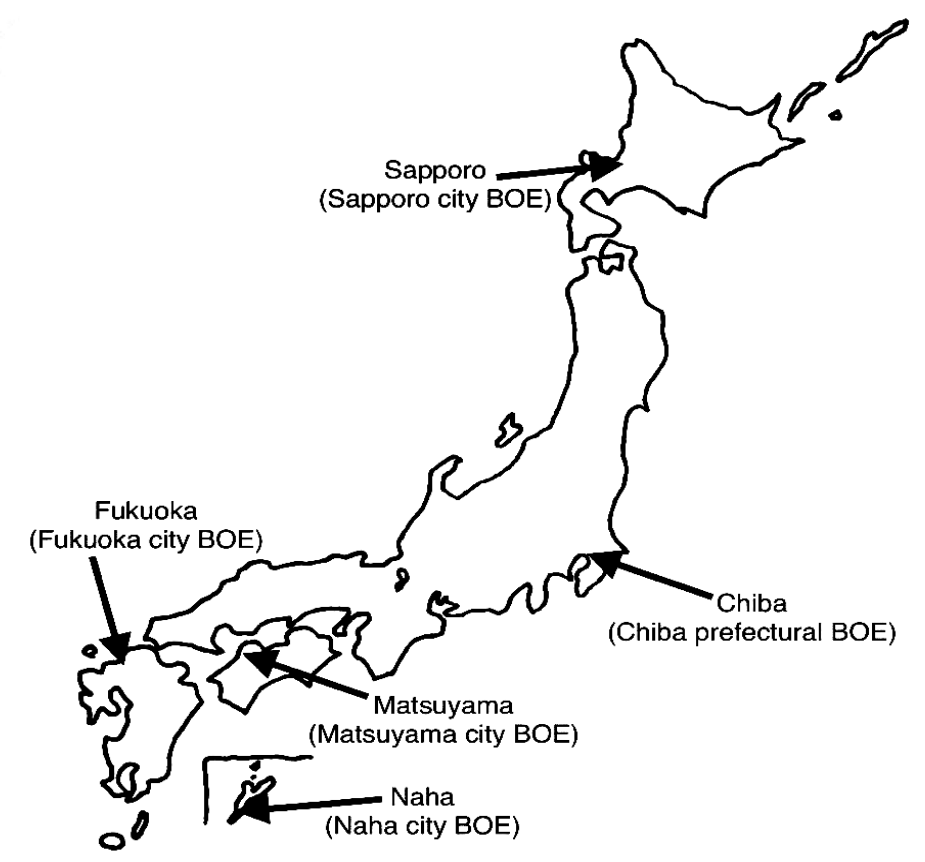

Figure 1. Location of BOEs examined.

Some BOEs, such as Sapporo and Chiba, publicly provide the reasons they use for adopting particular texts (see Appendix, Documents 2, 4, and 5.) The Chiba prefectural
BOE includes a detailed evaluation checklist. In contrast, the Fukuoka municipal $\mathrm{BOE}$ does not provide this information publicly, but when requested provided the document outlining their reasons for selection (see Appendix, Document 6.) The BOEs of Matsuyama and Naha did not provide any information regarding the selection process for coursebook adoption. As such, the selection processes of these two BOEs could not be examined. Unfortunately, Matsuyama BOE requires a visit to their office to make any sort of response related to enquiries relating to coursebook choices. Similarly, Naha declined to answer any enquiry, and their website states they have the right not to do so if the enquiry does not come from a governmental entity. Only Chiba's BOE publicly releases information to show that they consider more than one publisher's coursebook series. The data gathered from each BOE for school years starting from 2016 are outlined in Table 1.

Table 1. Coursebook Adoption Processes of Selected BOEs

\begin{tabular}{lccccc}
\hline Data point & Sapporo & Chiba & Matsuyama & Fukuoka & Naha \\
\hline $\begin{array}{l}\text { Adopted course } \\
\text { book series }\end{array}$ & Sunshine & $\begin{array}{c}\text { New Crown } \\
\text { Columbus 21 }\end{array}$ & Total English & Sunshine & Sunshine \\
$\begin{array}{l}\text { Information publicly } \\
\text { provided? }\end{array}$ & $\bigcirc$ & $\bigcirc$ & $\times$ & $\times$ & $\times$ \\
$\begin{array}{l}\text { Reasons for } \\
\text { adoption } \\
\text { documented }\end{array}$ & $\bigcirc$ & $\bigcirc$ & N/A & $\bigcirc$ & N/A \\
$\begin{array}{l}\text { Other publishers' } \\
\text { series considered }\end{array}$ & $\bigcirc *$ & $\bigcirc$ & N/A & $\bigcirc^{*}$ & N/A \\
$\begin{array}{l}\text { New publishers' } \\
\text { series adopted }\end{array}$ & $\times$ & $\times$ & $\times$ & $\times$ & $\bigcirc$ \\
$\begin{array}{l}\text { Evaluation checklist } \\
\text { used }\end{array}$ & $\bigcirc *$ & $\bigcirc$ & N/A & $\times^{*}$ & N/A \\
\hline
\end{tabular}

Note. N/A = Information not available.

* information received via direct correspondence

Table 2 is a list compiled by Watanabe (2015) that shows the Japanese JHS market share that each publisher had with their respective JHS English coursebook series. 
Table 2. JHS English Coursebook Series by Market Share ${ }^{2}$

\begin{tabular}{lllrc}
\hline Rank & Coursebook series & \multicolumn{1}{c}{ Publisher } & \multicolumn{1}{c}{ Sales } & Market share \\
\hline 1 & New Horizon & Tokyo-Shoseki & $1,139,929$ & $32.3 \%$ \\
2 & Sunshine & Kairyudo & 907,511 & $25.7 \%$ \\
3 & New Crown & Sanseido & 864,068 & $24.5 \%$ \\
4 & Total English & Gakko Tosho & 419,989 & $11.9 \%$ \\
5 & Columbus 21 & Mitsumura & 100,679 & $2.9 \%$ \\
6 & One World & Kyoiku Shuppan & 98,136 & $2.8 \%$ \\
\hline
\end{tabular}

Note. Information taken from Watanabe, 2015.

The first example of coursebook adoption documentation comes from Sapporo municipal BOE from 2015 (see Appendix Documents 1, 2, and 3 for original Japanese documentation). Sapporo BOE's website regarding the 2016 JHS English coursebook selection and its contents only mention the coursebook series that was adopted for each discipline (see Appendix, Document 1.) This documentation suggests that other coursebook series may not have been considered. For this reason, the Sapporo BOE was contacted to determine if this was the case or not. The Sapporo BOE then provided a research report on books for JHS subjects used from 2016 (see Appendix, Document 3.) This document is available for public reference at the Sapporo city office (Sapporo Board of Education, 2020). The criteria considered for the selection of coursebook series centers on two main points. First, criteria are used to assess the inclusion and quality of material in the coursebooks related to environmental awareness and preservation. Second, subject-specific criteria (in this case English language) are used to make judgments on the coursebooks' handling of materials in relation to (a) motivation, (b) elementary school to JHS progression, (c) balance of the four skills, (d) appreciation of Japanese culture, and (e) respect and understanding of other cultures,

In contrast, the Chiba prefectural BOE provides on their website information that includes selection statements that implement an evaluation rubric. Selection committees in Chiba prefecture are responsible for these selection statements. Two of such documents can be found on Chiba's official website, however, both include similar comments and recommend the same three coursebook series (see Appendix Documents 4 and 5). This rubric and its respective criteria are used to evaluate coursebooks of all subjects, including English, math, science, and Japanese. To this end, each selection committee in Chiba evaluates the MEXT-approved coursebook series using their criteria and indicates their preferences.

Chiba used their rubric to evaluate six coursebooks that were under consideration for adoption for the 2016 academic year. They used six different categories for evaluating the extent and quality of the content of the coursebooks:

1. the variety, progression, and depth of activities in the coursebooks;

2. its connection to moral education;

3. reference to health, nature, and disaster prevention;

4. the promotion of social and occupational independence;

5. focus on Japanese culture, foreign culture, and interdependence among nations; and

6. the potential to implement the curriculum based on educational goals of the schools concerned (Chiba Prefectural Board of Education, 2015a, 2015b).

The approaches to culture taken by Sapporo and Chiba prefecture follow research that suggests that students' recall improves if the content relates to their native cultures (Nelson, 1987). Furthermore, the use of native culture readings has been shown to result in improved reading skills (Nelson \& Schmidt, 1989). Sapporo and Chiba also include criteria that evaluate the coursebooks regarding how they reference environmental concerns, including nature preservation and disaster prevention. However, it is unclear whether the addition of these topics was done so with regard to any specific benefits to language acquisition.

Fukuoka municipal BOE provided documentation that included the selected coursebook series (Sunshine) along with its ranking (first). Fukuoka confirmed that all six coursebook series were considered and ranked. However, only the parts of this documentation with the adopted coursebook series were released by this BOE (Fukuoka City Board of Education, 2015). Fukuoka city's evaluations are separated according to criteria related to all subjects as well as subject criteria, in this case foreign languages (including English). Fukuoka's evaluation points seem to focus on the organization and execution of contents in three coursebooks. There were also points that mentioned particular coursebooks, for example that the first-grade book included visual cards, as well as taking into consideration previous language learning (elementary school education) or the organization of particular sections of the books, such as whether its activities are suitable for pair work. Consideration was also made of the extent to which 
coursebooks addressed respect for other cultures and how this raised students' interest in other languages and cultures. Note was also made of listening and dialogue practice activities present throughout the selected books, as these were not present in other publishers' series.

\section{Discussion}

In this study, I have noted some important differences in the criteria considered by BOEs in coursebook selection. The Chiba prefectural BOE evaluates coursebooks series (for any discipline) against six relatively broad criteria. Four of the six criteria focus on topical content and are more concerned with the medium in which the target language is presented. Coursebooks that meet these criteria are more likely to be selected over those that do not. In contrast, the Fukuoka municipal BOE appears to be more focused on the learning materials in regard to how they facilitate language learning particularly via the organization and execution of contents in the coursebooks. Fukuoka's evaluation points are largely concerned with the sections, activities, and learning tools in the three coursebooks. It is important to note that for this study, only the evaluation points concerning the coursebook series that was actually selected by Fukuoka municipal BOE could be examined. Finally, Sapporo's BOE considered six coursebook series using evaluation criteria that focus on topical and practical concerns. Topical concerns related to the medium in which the language materials are presented were similar to those of Chiba. These issues relate to concern for the environment and appreciation of Japanese and other cultures. Unlike the other BOEs, Sapporo also considered practical criteria relating to how well the coursebooks would transition students from elementary school English education and how balanced the execution of the four language skills was in the coursebooks. The evaluation methods of the three BOEs that were examined are summarized in Table 3.
Table 3. Coursebook Evaluation Methods Used by Sapporo, Chiba, and Fukuoka BOEs

\begin{tabular}{lll}
\hline BOE & Evaluation method & Number of coursebook
\end{tabular}
series considered

Sapporo Checklist containing all subject and subject specific criteria with specified justification

Chiba Six-criteria checklist (used for all subjects of study) with specified justification

Fukuoka Two category analysis of individual points and repeated coursebook elements

*Evaluation regarding one coursebook series could be examined in this study.

The outcomes of this study indicate that coursebook series are being selected by different BOEs based on a variety of methods and criteria. Chiba bases decisions about all subjects (math, science, Japanese, etc.) on the same evaluation rubric, rather than how well particular coursebook contents cater to language teaching and learning. Instead, Chiba gives more attention to how these books encourage motivation and cultural understanding. Fukuoka's report arguably went into the most depth in that much of its evaluation was concerned with how the contents facilitate language acquisition. While student motivation and interests were addressed in all three reports, none of the reports seemed to consider the needs of teachers. None of the evaluation criteria mention the usability of the coursebook, the teacher's manual, supplemental materials, or ease of use. However, selection committee members are generally teachers, former teachers, and parents. As such, there may have been indirect consideration of the needs of teachers' needs, based on the teaching experiences of committee members.

A particularly noteworthy finding was that all three of the BOEs evaluated coursebooks with respect to facilitating student transition from elementary to JHS and high school. One of the advantages of doing so is that it considers the familiarity of students with particular learning-related activities when students transition during their English education at school. This also potentially makes teachers' jobs easier due to student and teacher task familiarity. This selection strategy also aids continuity for publishers, as it encourages them to make coursebooks that facilitate transition. However, the emphasis on continuity could make BOEs reluctant to adopt other coursebook series that may be better suited to the learning needs of students at 
particular levels. Any changes in coursebook selection would likely impact coursebook adoption at other levels of study, and this could lead to BOEs forgoing other possible coursebooks and discourage teaching innovation (McGrath, 2016).

The diversity in coursebook adoption processes was an interesting discovery. All three of the BOEs explored in this study evaluated texts with regard to environmental and cultural contents. While there is evidence that contents that represent native culture can be a motivating aid to learning (Nelson, 1995), little is known about how a focus on environmental consciousness could improve language acquisition. However, the outcomes of this study also indicate that BOEs may need to consider the effects of prioritizing certain criteria when these may hamper the selection of coursebooks that better meet learning and teaching needs and aims. Further investigation of other BOEs would help to clarify the similarities and differences among BOEs in JHS English coursebook selection and how these relate to curricular aims and the aims of MEXT.

\section{Conclusion}

Tomlinson and Masuhara (2010) stated that coursebook selection is "a crucial matter for those who consider the coursebook an indispensable material for instruction and learning" (p. 336). In Japan, coursebook use is estimated to make up nearly three quarters of the time that JHS students are in the English classroom. Since the selection of coursebooks has ongoing implications for learning and teaching, it seems reasonable that significant attention should be given to the coursebook adoption processes used among BOEs. One solution to the challenges presented in coursebook selection by different municipalities and prefectures may be the universal adoption of a simpler, yet effective rubric by BOEs across Japan. This may better serve the users of the coursebooks, as well as promote necessary growth in coursebook design and approaches to teaching, such as a closer alignment with SLA research for coursebook publishers. An approach of considering English language education globally across Japan while acting individually at the level of each BOE may lead to more emphasis being placed on local context such as learner interests and teacher satisfaction.

Notes

1. Remarks are based on comments via direct consultation with Robert S. Murphy in 2018.

2. Information for those curious about the sales of MEXT-approved JHS English coursebook series.
Bio Data

David A. Hammett worked in junior high schools in Japan for 6 years. He now works at the university level in Hokkaido teaching English. <hda.sapporo@gmail.com>

\section{References}

Azarnoosh, M., Zeraatpishe, M., Faravani, A., \& Kargozari, H. (2018). Issues in coursebook evaluation. Leiden, The Netherlands: Brill.

Chiba Prefectural Board of Education. (2015a). 平成28年度使用県立千葉中学校教科用図書選定理 由書 [For junior high school and secondary school preliminary course: reason for selection of books for subjects to be used from 2016 at Chiba JHS]. Chiba Prefecture: Chiba Prefectural Board of

Education. Retrieved from https://www.pref.chiba.lg.jp/kyouiku/shidou/shou-chuu/kyoukasho/ documents/chibajh.pdf

Chiba Prefectural Board of Education. (2015b). 平成28年度使用県立東葛飾中学校教科用図書選定理 由書 [For junior high school and secondary school preliminary course: reason for selection of books for subjects to be used from 2016 at Higashi Katsushika JHS]. Chiba Prefecture: Chiba Prefectural Board of Education, Retrieved from https://www.pref.chiba.lg.jp/kyouiku/shidou/shou-chuu/ kyoukasho/documents/toukatsujh.pdf

Fennelly, M., \& Luxton, R. (2011). Are they ready? On the verge of compulsory English, elementary school teachers lack confidence. The Language Teacher, 35(2), 19-23.

https://doi.org/10.37546/JALTTLT35.2

Fukuoka City Board of Education. (2015). 回答 (質問) 中学校英語の教科書について [Answer (Question) about junior high school textbooks]. Fukuoka City Hall: Fukuoka City Board of Education.

Glasgow, G., \& Paller, D. (2013, November). MEXT-approved EFL textbooks and the New Course of Study. Paper presented at the JALT2013, Tsukuba, Japan.

Grant, N. (1987). Making the most of your textbook. Harlow, England: Longman.

Hino, N. (2018). English as an international language for Japan: historical contexts and future prospects. Asian Englishes, 20(1), 27-40.

Littlejohn, A. (2011). The analysis of language teaching materials: Inside the Trojan Horse. In B Tomlinson (Ed.), Materials development in language teaching (pp. 179-211). London, England: Cambridge University Press.

McGrath, I. (2016). Materials evaluation and design for language teaching (2nd ed.). Edinburgh, Scotland: Edinburgh University Press.

MEXT. (2008). 中学校学書指導要領外国語英語版仮役 [Course of Study Guidelines for foreign languages in junior high schools; provisional version]. Retrieved from www.mext.go.jp/a_menu/shotou/newcs/ youryou/eiyaku/1298356.htm. 
MEXT. (2014). Report on the Future Improvement and Enhancement of English Education (Outline): Five recommendations on the English Education Reform Plan responding to the rapid globalization. Retrieved from http://www.mext.go.jp/en/news/topics/detail/1372625.htm.

MEXT. (2017). 中学校学習指導要領(平成 29 年告示)解説: 外国語編 Junior High School Study Guide (Notification in 2017): Foreign language edition]. Retrieved from http://www.mext.go.jp/ component/a_menu/education/micro_detail/__icsFiles/afieldfile/2018/05/07/1387018_10_1. pdf.

MEXT. (2019). 教科書Q\&A [Textbook $Q \& A]$. Retrieved from

https://www.mext.go.jp/a_menu/shotou/kyoukasho/010301.htm\#05.

Nelson, G. (1987). Culture's role in reading comprehension: A schema theoretical approach. Journa of Reading, 30(5), 424-429.

Nelson, G. (1995). Considering culture: Guidelines for ESL/EFL textbook writers. In P. Byrd (Ed.), Material writer's guide (pp. 23-42). Boston, MA: Heinle \& Heinle.

Nelson, G., \& Schmidt, T. (1989). Reading: Schema theory and standardized tests. TESOL Quarterly, 23(3), 539-543. https://doi.org/10.2307/3586928

O'Neill, R. (1993). Are textbooks symptoms of a disease? Practical English Teaching, 14(1), 3.

Richards, J. (2001). The role of instructional materials. In J. Richards (Ed.), Curriculum development in language teaching (pp. 251-285). Cambridge, England: Cambridge University Press.

Sanseido Publications. (2017). 中学校英語 Q\&A [Junior high school English Q\&A]. Retrieved from https://tb.sanseido-publ.co.jp/faq/qaj-school/faqj-english/

Sapporo Board of Education. (2015a). 平成28年度から使用する中学校及び中等教育学校前期課程 用 教科用図書選定理由書 [For junior high school and secondary school preliminary course: Reason for selection of books for subjects to be used from 2016]. Sapporo City: Sapporo City Board of Education. Retrieved from http://www.city.sapporo.jp/kyoiku/kyokasyo/documents/07chuu_ riyu.pdf

Sapporo Board of Education. (2015b). 平成28年度から使用する中学校用、中等教育学校 (前期課程) 用 教科用図書調查研究報告書 (答申)「外国語委員会 [Book research report (report) for junior high schools and secondary education schools (first semester) to be used from 2016, "Foreign language committee"]. Sapporo City: Sapporo City Board of Education.

Sapporo Board of Education. (2020, March 8). [【札幌市教育委員会】中学校の英語教科書について [Sapporo Board of Education - About English textbooks in junior high school].

Tahira, M. (2012). Behind MEXT's New Course of Study guidelines. The Language Teacher, 36(3), 3-8. https://doi.org/10.37546/JALTTLT36.3

Tomlinson, B., \& Masuhara, H. (2017). The complete guide to the theory and practice of materials development for language learning. London, England: Wiley-Blackwell.

Ur, P. (1996). A course in language teaching: Practice and theory. Cambridge, England: Cambridge University Press.
Watanabe, A. (2015). 教科書採択[Textbook adoption]. 内外教育[Home and Abroad Education]. Tokyo: 時事通信社 [jiji Press].

Yuen, K. (1997). Review of Allwright's (1981) paper “Why use textbooks?” BEd Assignment.

Nottingham: University of Nottingham.

Appendix 1

Sapporo Municipal BOE's Documentation for Selection of Coursebook Series

小学校外国語活動との接続を丁寧に扱うとともに、本文で、国連におけるマララさんのスピーチを取 り上げるなど、心を摇さぶる題材を揭載したり、身に付けるべき力をリス卜形式で示したりすること で、学ぶ意欲を高めることが可能な内容となっている。また、ぺア学習やグループ活動の中で、より 良い表現について互いにアドバイスをする活動を取り入れるなど、適切な表現力を高めることが可 能な構成となっている。

(Sapporo Board of Education, 2015a) 
Hammett: English Coursebook Adoption Processes for Junior High Schools in Japan

\section{Appendix 2}

Sapporo Municipal BOE's Documentation of JHS English Coursebook Selection Criteria

\begin{tabular}{|c|c|c|c|c|}
\hline \multicolumn{3}{|l|}{ 別紙 } & \multirow{2}{*}{\multicolumn{2}{|c|}{ 札幌市として設定する調査研究項目 }} \\
\hline 教科 & & \begin{tabular}{l|l|} 
外国語 & 種目 \\
\end{tabular} & & \\
\hline No. & & 調查研究項目〈設定の理由〉 & 具体項目 & 調查研究の具体的内容 \\
\hline \begin{tabular}{|l|} 
蓪 \\
筧 \\
\end{tabular} & 1 & 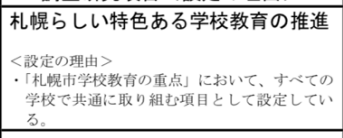 & (1) [㻴填] 亿闌办万題材 & 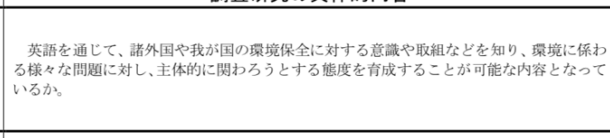 \\
\hline \multirow{4}{*}{ 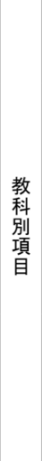 } & \multirow{3}{*}{2} & $\begin{array}{l}\text { 自ら学ぶ喜びを実感できる学習活動 } \\
\text { の推進 }\end{array}$ & 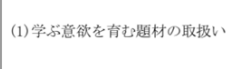 & 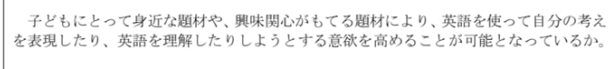 \\
\hline & & 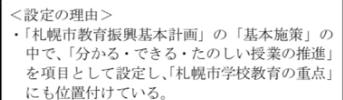 & 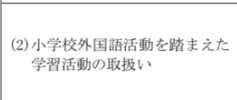 & 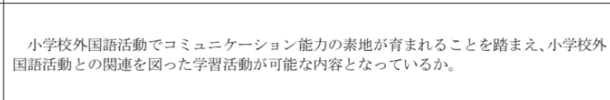 \\
\hline & & 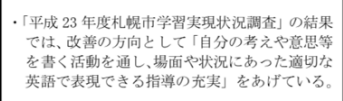 & 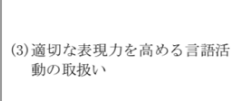 & 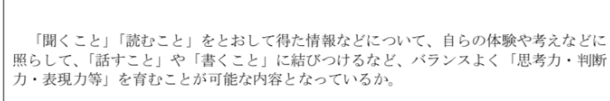 \\
\hline & 3 & 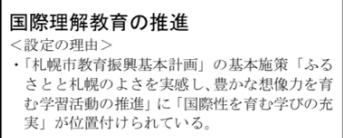 & 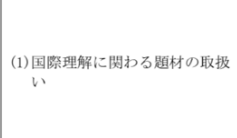 & 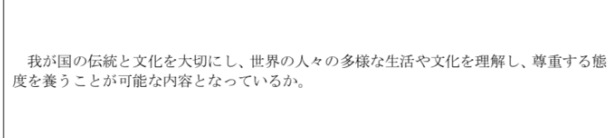 \\
\hline
\end{tabular}

(Sapporo Board of Education, 2016)

\section{Appendix 3}

Documentation Excerpts Regarding JHS English Coursebook Examination

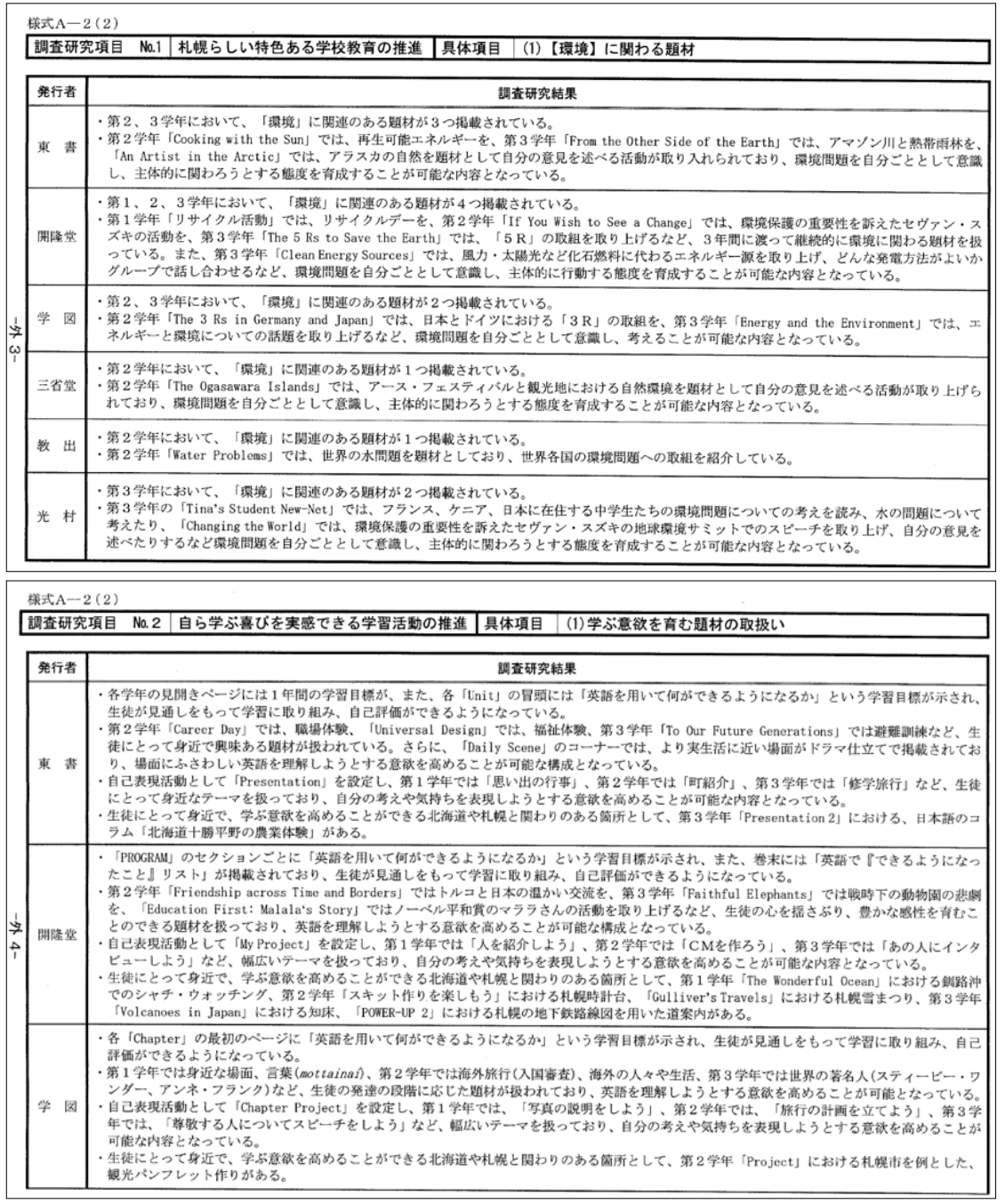

(Sapporo Board of Education, 2015b) 
Appendix 4

Chiba Prefectural BOE's Documentation for Selection of Coursebook

\section{Series (1)}

\begin{tabular}{|c|c|c|c|}
\hline \multicolumn{4}{|c|}{ (種目 : 英語) } \\
\hline 推薦 & & 0 & \\
\hline 観 & 登行者: 2 - 東京書籍 & 登行者: 9 開隆黨 & 登行者: 111 学校圈書 \\
\hline 点 & (書名: NEW HORIZON) & (書名: SUNSHINE) & (書名: TOTAL ENGLISH) \\
\hline (1) & 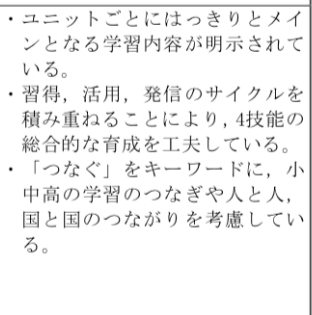 & 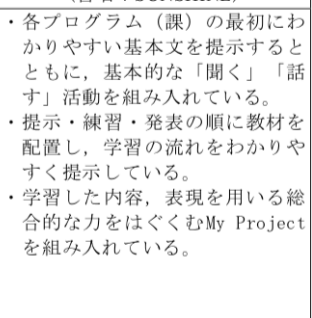 & 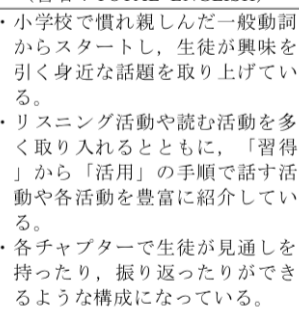 \\
\hline (2) & 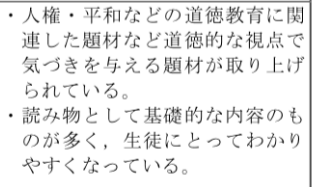 & 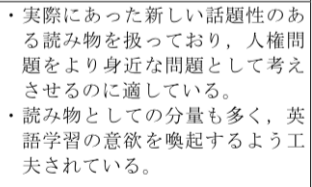 & 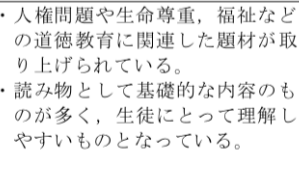 \\
\hline (3) & 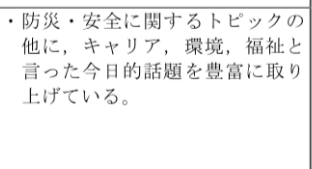 & 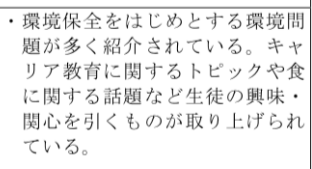 & 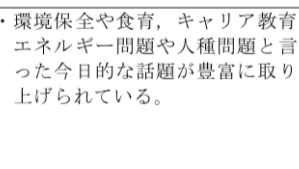 \\
\hline (4) & 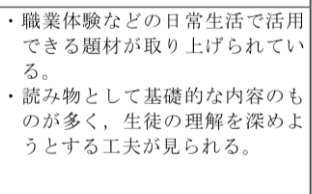 & 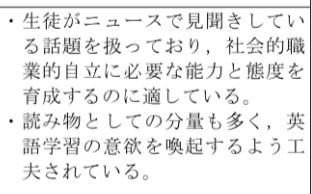 & 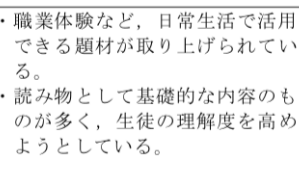 \\
\hline (5) & 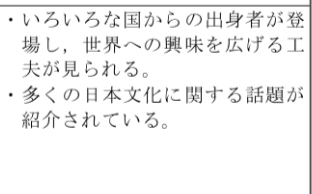 & 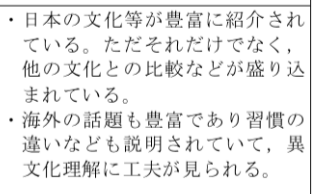 & 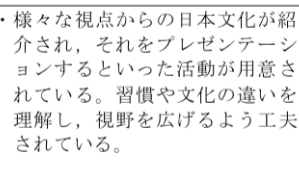 \\
\hline (6) & 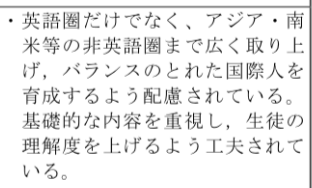 & 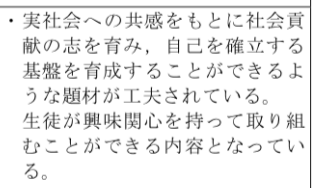 & 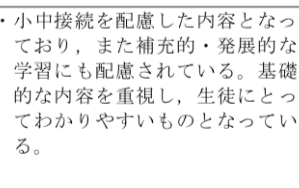 \\
\hline
\end{tabular}

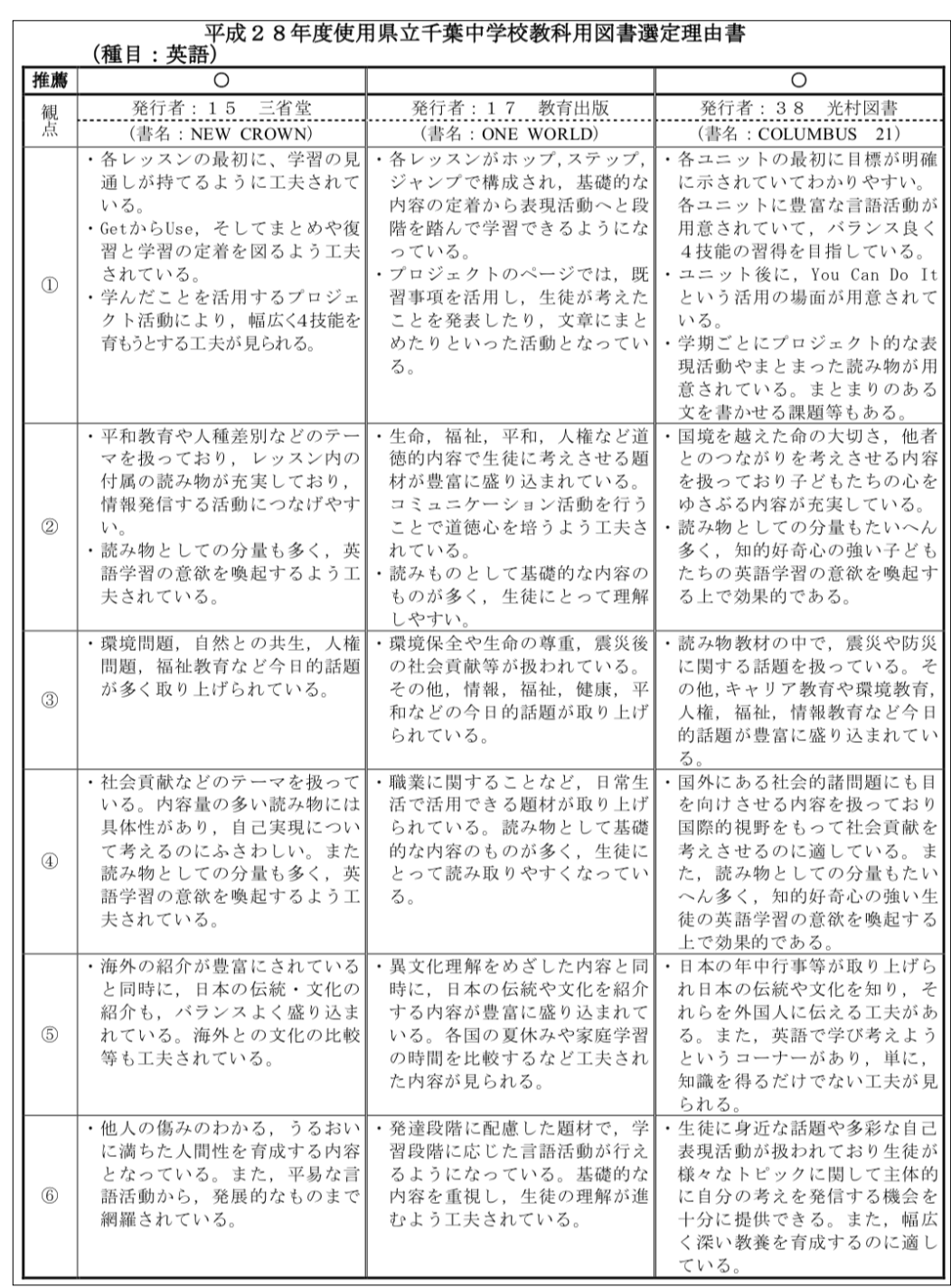

(Chiba Prefectural Board of Education, 2015a) 
Appendix 5

Chiba Prefectural BOE's Documentation for Selection of Coursebook Series (2)

\begin{tabular}{|c|c|c|c|}
\hline \multicolumn{4}{|c|}{$\begin{array}{l}\text { 平成 } 28 \text { 年度使用県立東暮飾中学校教科用図書選定理由書 } \\
\text { (種目 : 英語) }\end{array}$} \\
\hline 推薦 & & 0 & \\
\hline 襸 & 発行者：2 束京書籍 & 発行者: 9 開隆堂 & 発行者：11 学校图書 \\
\hline 点 & (書名 : NEW HORIZON) & (書名: SUNSHINE) & (書名 : TOTAL ENGLISH) \\
\hline (1) & 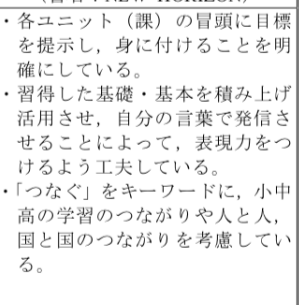 & 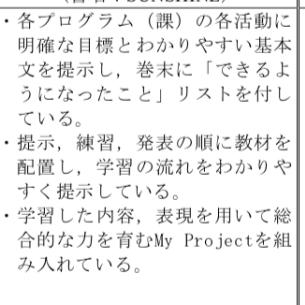 & 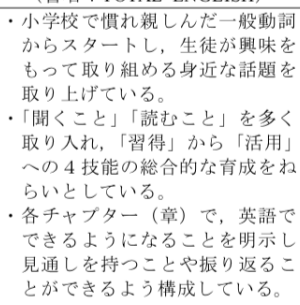 \\
\hline (2) & 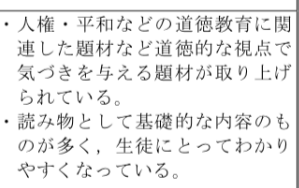 & 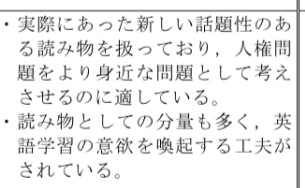 & 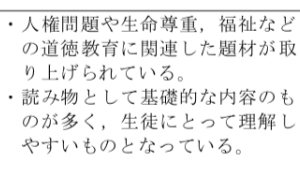 \\
\hline (3) & 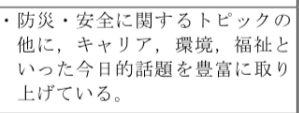 & 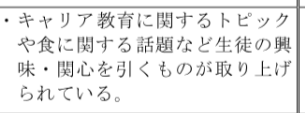 & 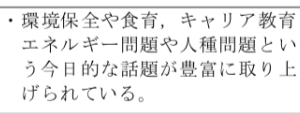 \\
\hline (4) & 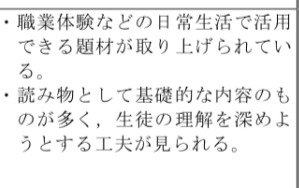 & 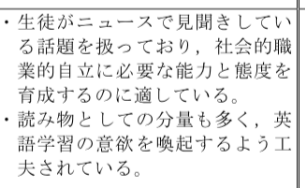 & 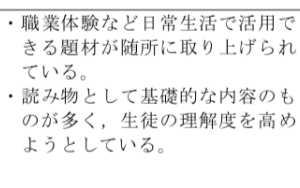 \\
\hline (5) & 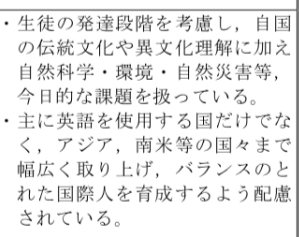 & 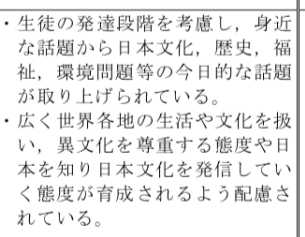 & 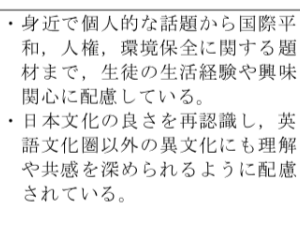 \\
\hline (6) & 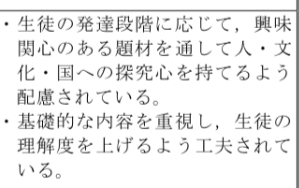 & 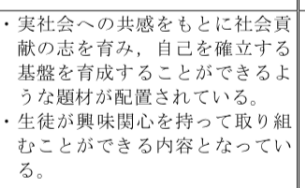 & 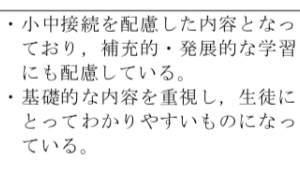 \\
\hline
\end{tabular}

平成 28 年度使用県立東葛飾中学校教科用図書選定理由書

\begin{tabular}{|c|c|c|c|}
\hline 推葴 & 0 & & 0 \\
\hline 知 & 発行者: 115 三省堂 & 發行者: $: 17$ 教育出版 & 発行者: $: 38$ 光村国暃 \\
\hline & (書名: NEW CROWN) & (書名：ONE WORLD) & (畒名: COLUMBUS 21) \\
\hline \multirow{9}{*}{ (1) } & $\begin{array}{l}\text { ·各レッスンの冒頭で学習の見通 } \\
\text { しを持たせ, 巻末にはANDON }\end{array}$ & 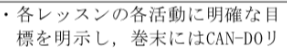 & 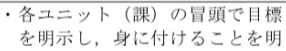 \\
\hline & ストを配㜔している。 & ス卜を配媈している。 & 碓にしている。 \\
\hline & 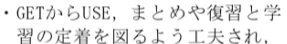 & 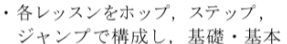 & 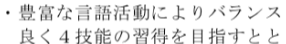 \\
\hline & 筫・量ともに古実している。 & 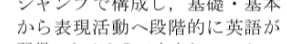 & もに, ニニット後に, You Can \\
\hline & - 各活動が順序上く配濁され，基 & 畾得てきるようエ夫されている。 & Do Itと以ら活用の堎面ふ用意 \\
\hline & 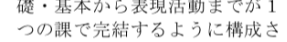 & 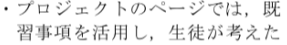 & $\begin{array}{l}\text { されている } \\
\text { 学期ごとにプロジェクト的 }\end{array}$ \\
\hline & れたいる。 & ことを発表したり，文章にまと & 現活動やまとまった趐 \\
\hline & 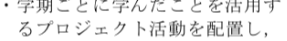 & & 值されている。 \\
\hline & 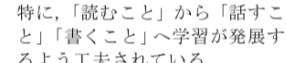 & & \\
\hline \multirow{7}{*}{ (2) } & - 平和教育や人種 & ·生命，福祉，平和，人锥など道 & 国境を越えた命の大切さ，他者 \\
\hline & 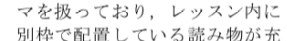 & 德的P & 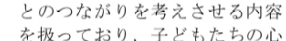 \\
\hline & 実してた找り，情報発信寸る & .コミュニケー & れゆさららる内容が多くある。 \\
\hline & につなげやすく & ことで & 范丈物としての分量 \\
\hline & ・読み物 & れ, & 好奇心の強い生 \\
\hline & 語学習の意 & 容のも & 题ナるよう \\
\hline & 夫さ & 理解 & \\
\hline & 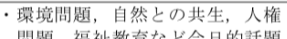 & - 情䡮, 视 & キャリ \\
\hline (3) & 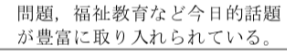 & $\begin{array}{l}\text { 今日 } \\
\text { 亏。 }\end{array}$ & $\begin{array}{l}\text { 福祉, 情報教育子 } \\
\text { 方报われてら。 }\end{array}$ \\
\hline \multirow{6}{*}{ (4) } & - 社会頁献などの & ·睵業! & 10 \\
\hline & 㧍り & 活て & を占 \\
\hline & 具体性があ & & 国際的 \\
\hline & $\begin{array}{l}\text { て考えるのにふさわしい内容と } \\
\end{array}$ & 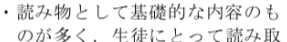 & 考えさせることと適している。 \\
\hline & 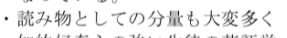 & りやすくなってい & 好奇心の強い生徒の英 \\
\hline & $\begin{array}{l}\text { 知的脄 } \\
\text { 習の尊 }\end{array}$ & & るよう土夫されて \\
\hline \multirow{6}{*}{ (5) } & ・ことば, 伝統义 & & 4) \\
\hline & & & $-x_{5}$ \\
\hline & & & 随所它光 \\
\hline & ·日本一 & • 世? & 和食 \\
\hline & 题材 & & \\
\hline & & 变を有 & \\
\hline \multirow{8}{*}{ (6) } & 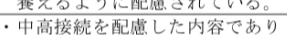 & 發上 & 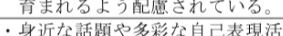 \\
\hline & & & \\
\hline & & & \\
\hline & & & w \\
\hline & & & \\
\hline & & & a \\
\hline & 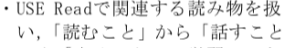 & & \\
\hline & 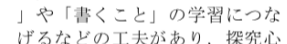 & & \\
\hline
\end{tabular}

(Chiba Prefectural Board of Education, 2015b) 


\section{Appendix 6}

Fukuoka Municipal BOE's Documentation for Selection of Coursebook Series (Regarding Chosen Coursebook Only)

\begin{tabular}{|c|c|c|c|c|}
\hline \multicolumn{5}{|c|}{ 政科用図書（英語） } \\
\hline 教科書種目 & \multicolumn{2}{|r|}{ 発 行 者 } & \multirow[t]{2}{*}{ 書 } & 使用学年 \\
\hline 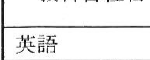 & & \begin{tabular}{|c|} 
発行者名 \\
䦥隆堂出版 \\
\end{tabular} & & $1 \sim 3$ 年 \\
\hline \multicolumn{5}{|c|}{ 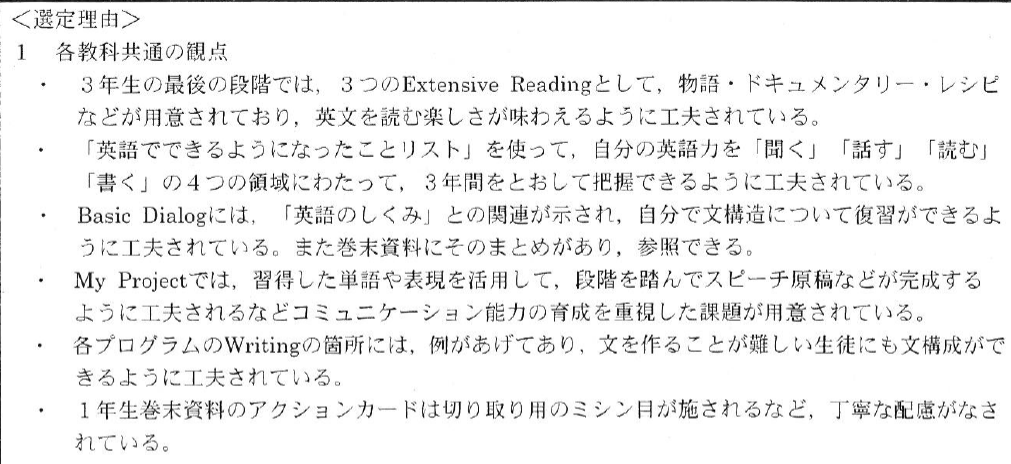 } \\
\hline \multicolumn{5}{|c|}{ 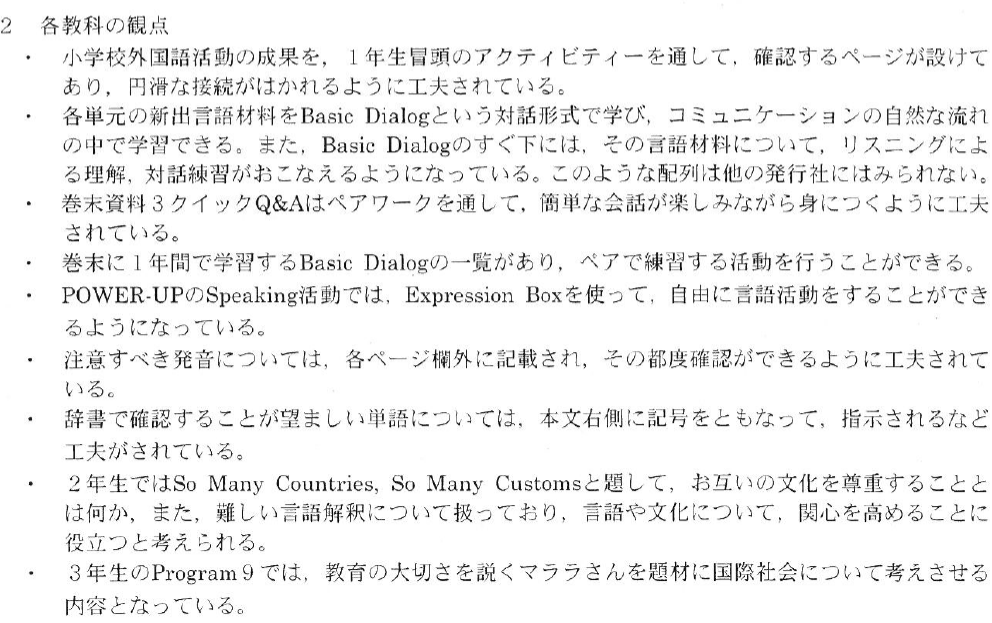 } \\
\hline
\end{tabular}

(Fukuoka City Board of Education, 2015)

\section{W FRONT PAGE}

